\title{
PEMODELAN EKSPANSI STENT JANTUNG DENGAN BALON HYPER - ELASTIS
}

\author{
Donny Suryawan ${ }^{1}$, Suyitno ${ }^{2}$ \\ Jurusan Teknik Mesin ${ }^{1}$, Teknik Industri ${ }^{2}$, Fakultas Teknik Universitas Gadjah Mada \\ Jl. Teknika., Bulaksumur, Yogyakarta \\ Email :donny_s@ymail.com',Suyitno@ugm.ac.id ${ }^{2}$
}

\begin{abstract}
Coronary artery disease (CAD) is a disease that most cause mortality in Indonesia. CAD is caused by cholesterol-containing deposit (plaque) that make the coronary artery become narrow and can cause a heart attack. Stent implantation is the most common treatment to opens or alleviates the narrowing coronary artery. A preliminary study has done to simulate the expansion of coronary stent with negligible balloon method. The negligible balloon is less accurate and far from realistic condition because it neglects the presence of the balloon. This study has proposed another method to simulate the stent expansion. Hyper-elastic balloon method is used to investigate the stress distribution, outer diameter change, and dogboning phenomena of the stent.
\end{abstract}

Keywords : Design, Stent, Modelling, Manufakturing.

\section{PENDAHULUAN}

Penyakit jantung koroner (PJK) adalah salah satu penyakit yang banyak menyebabkan kematian. PJK terjadi karena penyumbatan atau penyempitan pada arteri koroner sehingga menyebabkan darah tidak mengalir dengan lancar dan jantung menjadi bekerja lebih keras dari biasanya. Pada tahun 2013, lebih dari 2 juta orang terdiagnosa dan terindikasi menderita PJK (Data Centre and Information of Indonesian Health Ministry, 2013).

Beberapa upaya perawatan untuk penderita penyakit jantung koroner adalah dengan melakukan operasi bypass atau dengan memasang stent jantung. Pilihan kedua menjadi alternatif yang banyak digunakan karena biayanya relatif lebih murah dibanding dengan operasi bypass. Stent merupakan salah satu perlengkapan medis yang sampai saat ini masih bergantung dari impor. Penelitian ini menawarkan salah satu upaya untuk mengurangi ketergantungan impor stent yaitu dengan memproduksi secara mandiri. Pembuatan desain dan pemodelan merupakan salah satu langkah awal sebelum proses manufaktur. Pemodelan merupakan salah satu metode alternatif untuk membuat banyak skenario terkait geometri, material ataupun strategi lain untuk menghasilkan suatu gambaran fungsi produk tersebut sebelum dibuat atau dimanufaktur. Pemodelan cukup penting sebagai alat riset untuk kemudian divalidasi dengan hasil eksperimen. Pada penelitian ini, hasil pemodelan akan menjadi pertimbangan terkait catatan - catatan desain sebelum di manufaktur. Tentunya kemudahan manufaktur menjadi salah satu kunci utama agar stent mampu dibuat dengan Electrical Discharge Machine (EDM). Mesin EDM dipilih untuk proses manufaktur stent dengan pertimbangan mahalnya mesin laser cutting produksi stent.

Studi terkait pemodelan stent cukup banyak ditemukan diliteratur. Terdapat beberapa strategi untuk memodelkan ekspansi stent. Strategi ekspansi stent dengan mengabaikan balon adalah salah satu strategi yang paling sederhana (David Chua SN, 2002, Gu, L., Santra, S., Mericle, R.A., et al, 2005). Tekanan diberikan langsung pada permukaan dalam stent dan mengabaikan efek dari ekspansi balon. Skenario pemberian tekanan juga diperlukan supaya gaya ekspansi yang dihasilkan sama dengan gaya ekspansi yang dihasilkan saat balon diperhitungkan (Suryawan. D and Suyitno, 2016). Kelebihan dari strategi ekspansi yang mengabaikan balon adalah komputasi yang cepat dan tidak membutuhkan sumber komputasi yang tinggi. 
Hal tersebut terjadi karena diabaikannya interaksi stent dengan balon. Strategi ekspansi lain yang dapat digunakan adalah dengan memodelkan balon menggunakan material hyper - elastis. Strategi tersebut cukup baik untuk mengivestigasi ekspansi stent karena memperhitungkan kontak balon dengan stent (Esghi, N, M. H. Hojjati, M. Imani, A. M. Goudarzi, 2011).

Pada penelitian ini pemodelan dilakukan dengan menggunakan balon hyper - elastis untuk mengetahui deformasi, distribusi tegangan dan fenomena dogbone pada ekspansi stent yang dilakukan.

\section{METODE PENELITIAN}

\subsection{Geometri Model}

Model stent jantung yang digunakan adalah desain dengan pertimbangan kemudahan manufaktur menggunakan EDM (Suryawan. D and Suyitno, 2016). Pertimbangan tersebut meliputi pemilihan bentuk lubang yang sederhana. Stent di desain dengan panjang $10 \mathrm{~mm}$. Panjang tersebut disesuaikan dengan produk komersil stent yang telah beredar dipasaran. Ukuran diameter dalam yang digunakan adalah sebesar2 $\mathrm{mm}$ dan diameter luar adalah sebesar $2.6 \mathrm{~mm}$. Ukuran diameter tersebut dibuat dengan mempertimbangkan kemampuan mesin bubut konvensional dalam menyediakan bahan stent. Panjang lubang stent adalah $2 \mathrm{~mm}$ dan lebar lubang adalah $0.32 \mathrm{~mm}$. Desain stent dapat dilihat pada gambar 1 .

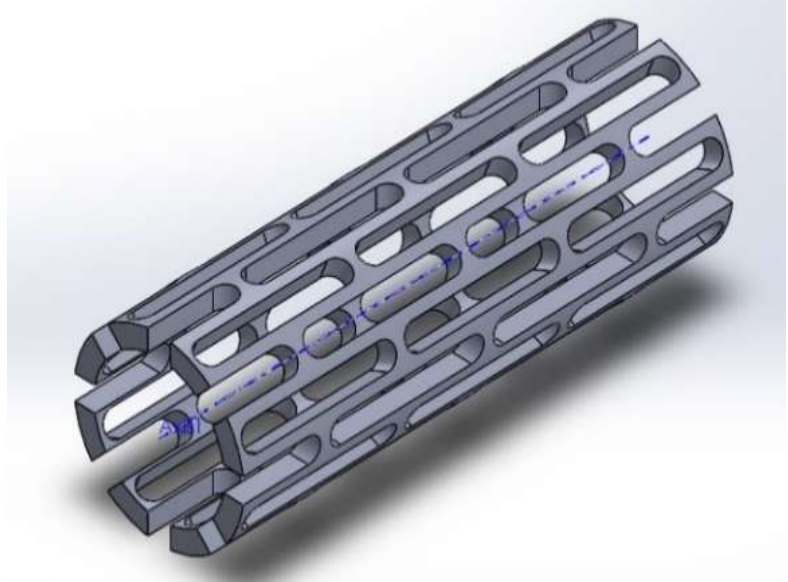

Gambar 1. Desain Stent.
Model balon yang digunakan adalah balon silinder hyper - elastis dengan panjang $10 \mathrm{~mm}$. diameter dalam dan diameter luar balon tersebut adalah $1.8 \mathrm{~mm}$ dan $2 \mathrm{~mm}$. Model keseluruhan antara stent dan balon hyper - elastis dapat dilihat padaGambar 2.

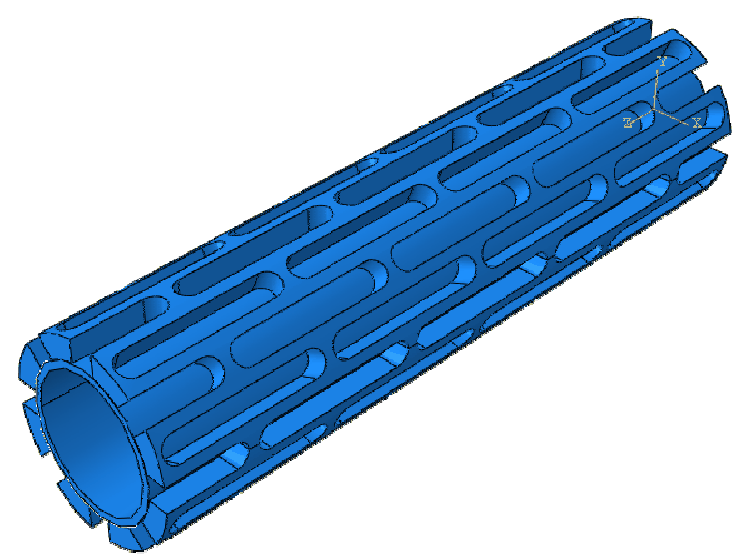

Gambar 2. Model Keseluruhan Stent dan Balon Hyper - Elastis.

\subsection{Spesifikasi Material}

Material yang digunakan untuk pemodelan stent adalah Stainless steel $316 \mathrm{~L}$. Spesifikasi material tersebut adalah modulus young sebesar $196000 \mathrm{~N} / \mathrm{mm}^{2}$, poison rasio sebesar 0.4 dan tegangan luluh sebesar 375 $\mathrm{N} / \mathrm{mm}^{2}$. Sedangkan Material balon di modelkan sebagai polyurethane yang di definisikan dengan hyper - elastis Mooney rivlin nonlinier orde pertama. Konstanta fungsi energi yang digunakan adalah $\mathrm{C}$ (10) $=1.06881 \mathrm{MPa}, \mathrm{C}(01)=0.710918 \mathrm{MPa}$ dan $\mathrm{d}=1070 \mathrm{Kg} / \mathrm{m}^{3}$ (Murphy, B.P., Savage, P., McHugh, P.E. 2003).

\subsection{Aspek Numerik}

Stent dimodelkan dengan elemen 8-node linear brick with reduce integration (C3D8R) yang terdiri dari 2376 elemen mesh. Sedangkan balon hyper-elastis dimodelkan dengan 6800 elemen 8-node linear brick with reduce integration (C3D8R). Pemodelan proses ekspansi stent dibagi dalam 4 tahap skenario. Skenario tersebut di adaptasi dari prosedur pemasangan stent. Skenerio pertama adalah tahap awal. Tahap awal adalah saat stent dan balon dalam kondisi normal tanpa beban apapun. 
Skenario kedua adalah tahap crimping atau tahap mengecilkan stent agar dapat dimasukan ke dalam pembuluh darah. Skenario ketiga adalah tahap ekspansi yaitu dengan memberikan tekanan pada permukaan dalam balon hingga stent mengembang. Skenario terakhir adalah tahap pelepasan tekanan. Tahap ini dilakukan saat stent sudah mengembang atau berekspansi.

Pemodelan proses ekspansi dilakukan menggunakan perangkat lunak $A B A Q U S$ dengan prosedur eksplisit. Variasi tekanan diberikan untuk mengetahui diameter akhir dari proses ekspansi dan besarnya dogbone akibat dari tekanan tersebut. Variasi tekanan yang diberikan adalah $1 \mathrm{MPa}, 1.25 \mathrm{MPa}, 1.5$ $\mathrm{MPa}, 1.75 \mathrm{MPa}$, and $2 \mathrm{MPa}$. Kondisi batas diberikan pada ujung - ujung balon dengan memaksa tidak ada deformasi aksial pada ujung balon. Definisi kontak yang digunakan adalah general contact.

\section{HASIL DAN PEMBAHASAN}

\subsection{Hasil Ekspansi}

Hasil pemodelan proses ekspansi dapat dilihat pada gambar 3. Secara umum, stent dapat berekspansi dengan baik akan tetapi fenomena dogbone tidak dapat dihindarkan.
Dogbone adalah fenomena perbedaan diameter bagian tepi stent dengan bagian tengah stent setelah proses ekspansi. Meski tak dapat dihindarkan fenomena dogbone harus diminimalkan karena dogbone yang terlalu besar akan menyebabkan luka pada pembuluh koroner. Fenomena dogbone terjadi karena pada bagian ujung stent lubang stent (cell) terbuka. Sehingga hanya ada dua strut yang menyangga deformasi stent. Hal tersebut menyebabkan bagian tepi stent lebih cepat dan lebih mudah terdeformasi sehingga menyebabkan diameter tepi stent lebih besar dibanding bagian tengah stent.

\subsection{Distribusi Tegangan}

Konsentrasi tegangan terjadi pada bagian tengah dari permukaan dalam stent. Hal tersebut terjadi karena tambahan tegangan yang diakibatkan oleh deformasi bagian tepi stent. Bagian tepi yang terdeformasi lebih cepat dan lebih besar menyebabkan bertambahnya tegangan tarik di bagian tengah dari permukaan dalam stent.Pada tekanan $2 \mathrm{MPa}$, tegangan maksimum yang terjadi adalah $367 \mathrm{MPa}$. Distribusi tegangan secara jelasnya dapat dilihat pada gambar 4.

\begin{tabular}{|c|ccccc} 
Kondisi Awal \\
Tahap \\
Trimping
\end{tabular}

Gambar 3. Proses Ekspansi. 


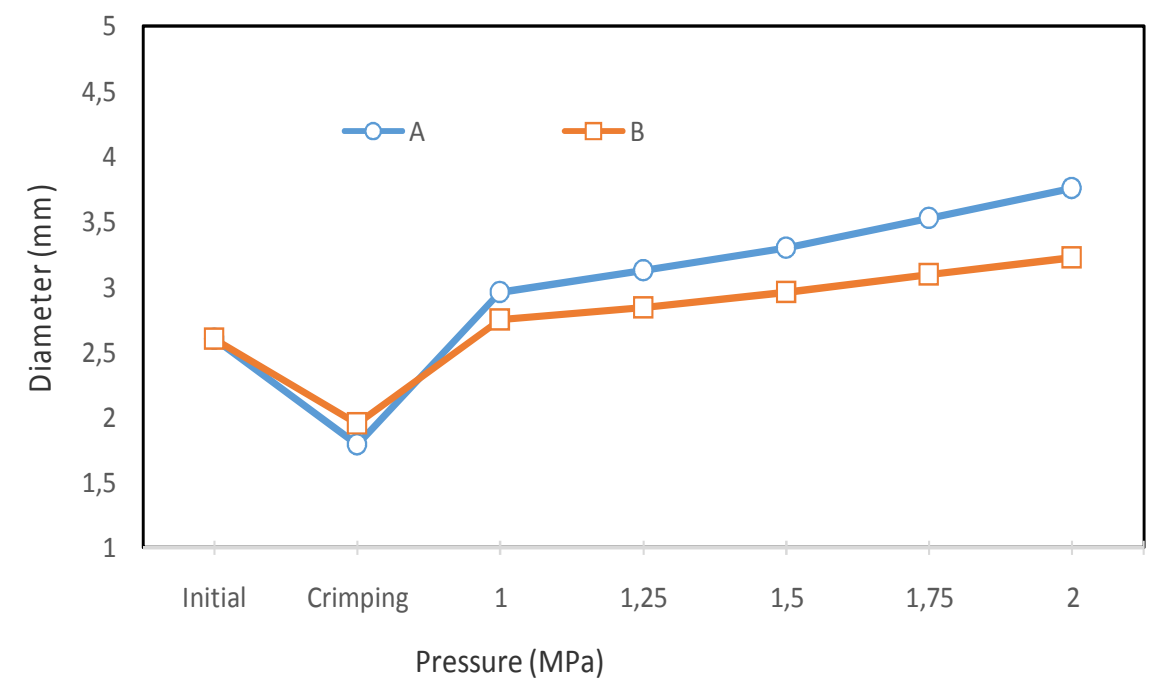

Gambar 4. Pengukuran Diameter Luar Stent Terhadap Variasi Tekanan.

\subsection{Perubahan Diamater Luar Stent}

Pengukuran diameter luar stent dilakukan pada dua bagian. Bagian pertama adalah diamater tepi stent (A) dan bagian kedua adalah diameter bagian tengah stent (B).

Pengukuran diameter menunjukan korelasi linier selisih diameter tepi dan tengah terhadap tekanan yang di berikan.
Semakin besar tekanan yang diberikan maka perbedaan diameter luar dengan diameter dalam stent semakin besar. Hal tersebut berarti juga bahwa prosentase dogbone juga semakin besar. Hasil pengukuran diameter luar stent secara lengkap dapat dilihat pada gambar 5.
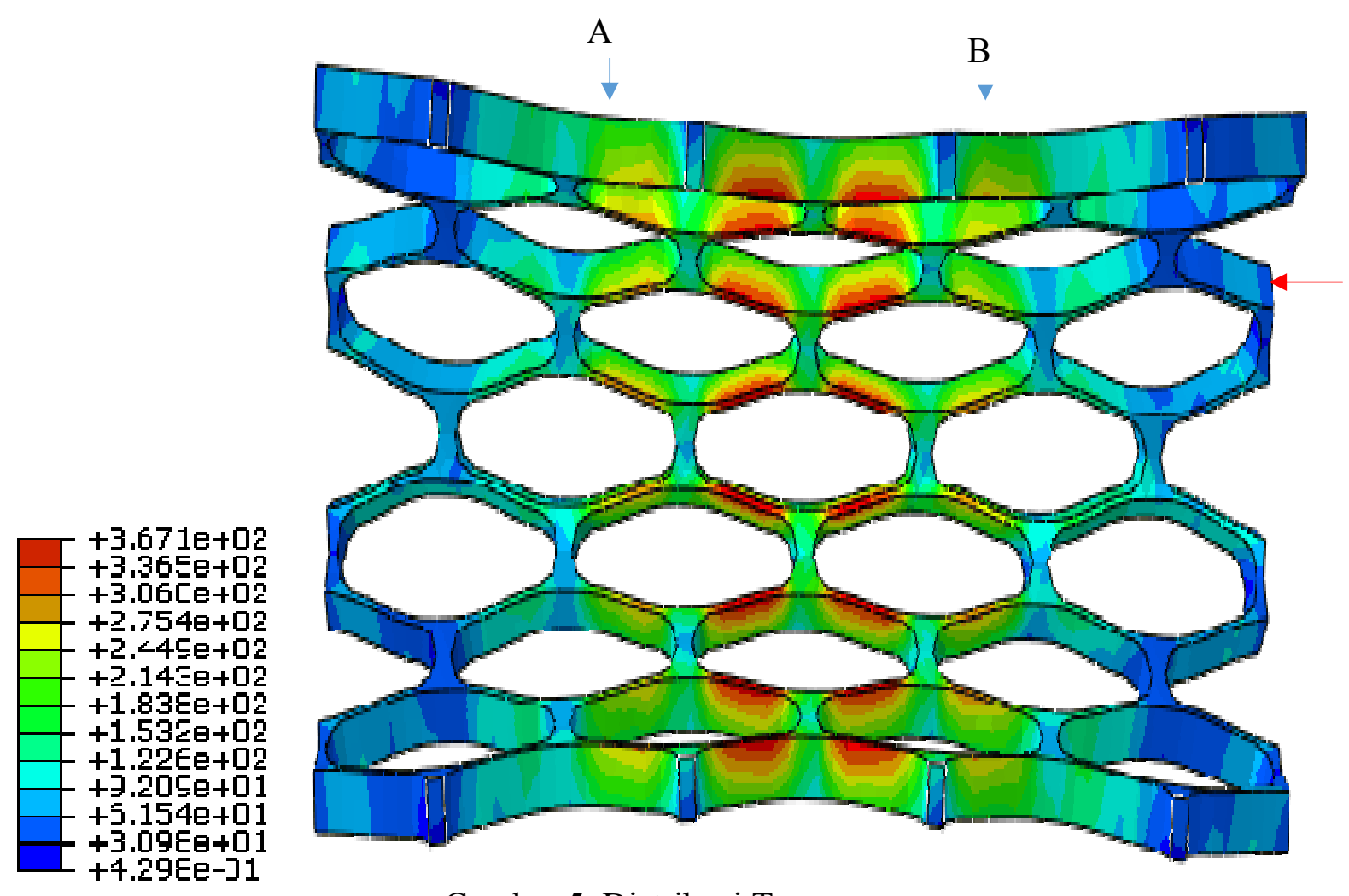

Open

Cell

Gambar 5. Distribusi Tegangan. 


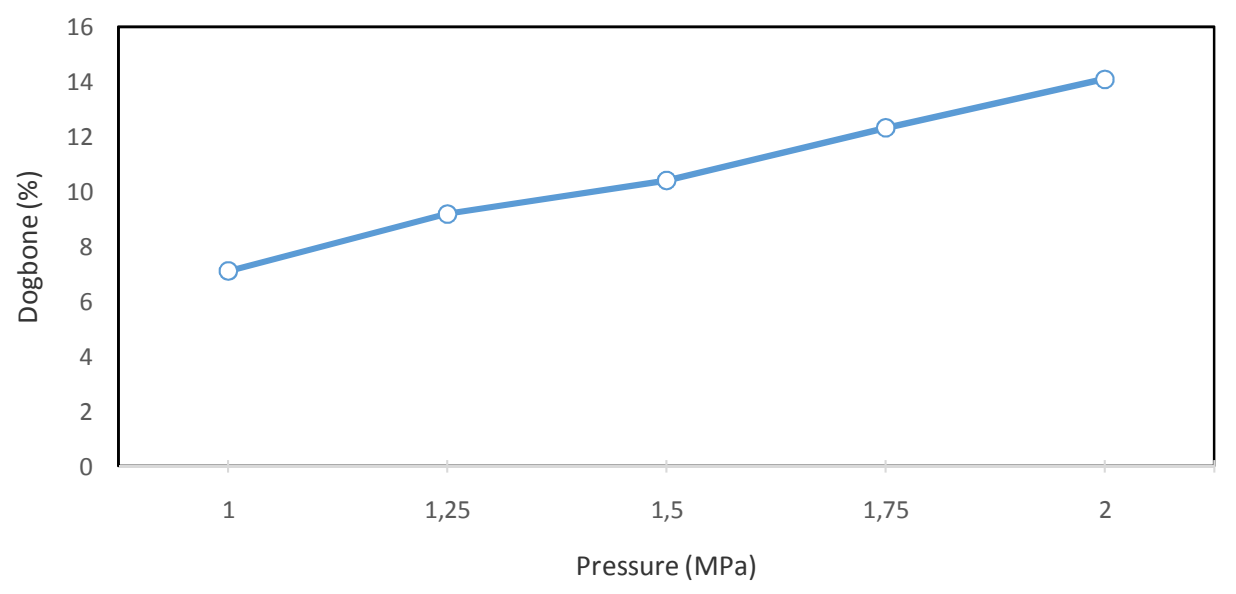

Gambar 6. Prosentase Dogbone.

\subsection{Prosentase Fenomena Dogbone}

Seperti yang dijelaskan sebelumnya, fenomena dogbone merupakan fenomena yang tidak dapat dihindari akan tetapi harus diminimalkan untuk mencegah terjadinya luka pada pembuluh koroner.

Luka pada pembuluh koroner dapat memicu terjadinya stent thrombosis atau penggumpalan darah pada daerah pemasangan stent. Prosentase dogbone paling kecil terjadi saat tekanan yang diberikan adalah $1 \mathrm{MPa}$. Prosentase akan semakin naik seiring dengan semakin tingginya tekanan yang diberikan.

\section{KESIMPULAN}

Hasil pemodelan menunjukan bahwa desain stent yang dibuat mampu berekspansi dengan baik. Hanya saja ada beberapa catatan yang harus diperhatikan antara lain pada beberapa titik masih terjadi konsentrasi tegangan yang cukup tinggi.

Konsentrasi tegangan tersebut terjadi karena gaya tarik deformasi pada tepi stent. Evaluasi dan optimasi desain stent tentunya masih perlu dilakukan untuk mengurangi adanya konsentrasi tegangan pada lokasi tertentu. Selain itu fenomena dogbone yang masih cukup besar pada tekanan tinggi juga perlu menjadi perhatian sebelum stent di manufaktur.

\section{DAFTAR PUSTAKA}

Auricchio, F., Di Loreto, M., Sacco, E. Finite-element analysis of a stenotic artery revascularization through a stent insertion. Computer Methods in Biomechanics and Biomedical Engineering 4, 249-263, 2001.

Data Centre and Information of Indonesian Health Ministry. The heart health condition. Indonesian Health Ministry. Indonesia : Jakarta, 2013.

David Chua SN, Mac Donald BJ, Hashmi MSJ. Finite - element Simulation of Stent Expansion. Journal of Materials Processing Technology; $120: 335$ - 40, 2002.

Esghi, N, M. H. Hojjati, M. Imani, A. M. Goudarzi. Finite Element Analysis of Mechanical Behaviour of A Coronary Stent. Procedia Engineering 10 (2011) 3056 - 3061, 2011.

Gu, L., Santra, S., Mericle, R.A., et al. Finite Element Analysis of Covered Microstents. Journal of Biomechanics 38, 1221 - 1227, 2005. 
Murphy, B.P., Savage, P., McHugh, P.E. The stress - strain behavior of coronary stent struts is size dependent. Annals of Biomedical Engineering 31, 686 - 691, 2003.

Suryawan. D and Suyitno. Design and modelling balloon-expandable coronary stent for manufacturability. Submitted to 11th Joint Conference on Chemistry, 2016. 